\title{
Pengaruh Waktu Maserasi Terhadap Aktivitas Antioksidan Ekstrak Daun Mundu (Garcinia dulcis (Roxb.) Kurz)
}

\section{The Influnce Of Maceration Time On Antioxidant Activity Of Mundu Ekstrak Leaf (Garcinia dulcis (Roxb.) Kurz)}

\author{
Setyo Widodo ${ }^{1}$, Ni Made Yusa ${ }^{1 *}$, Putu Timur Ina ${ }^{1}$ \\ Program Studi Ilmu dan Teknologi Pangan, Fakultas Teknologi Pertanian, Universitas Udayana \\ Kampus Bukit Jimbaran, Badung-Bali \\ *Penulis korespondensi: Ni Made Yusa, Email: madeyuse@unud.ac.id
}

\begin{abstract}
The research aimed to find effect of maceration time on antioxidant activity of mundu leaf extract and to know the best maceration time with highest antioxidant activity of mundu leaf extract. This study used a completely randomized design with treatment of maceration time 6 level: 12 hours, 24 hours, 36 hours, 48 hours, 60 hours, and 72 hours. The experiment was repeated in three replication, so that 18 experimental units were obtained. The variabels observed ware extraction yield, total tannin, total flavonoids, total phenol, and antioxidant activity. The data obtained were analyzed by ANOVA and if the treatment had significant effect followed by Duncan test. The result showed were maceration time has significant effect on extraction yield, total tannin, total flavonoids, total phenol, and antioxidant activity of mundu leaf extract. The best treathment was 24 hours with extraction yield was $24.67 \%$, total tannin was 133.04 mg.TAE/g, total flavonoids was $364.36 \mathrm{mg} . \mathrm{QE} / \mathrm{g}$, total phenol was $143.82 \mathrm{mg} . \mathrm{GAE} / \mathrm{g}$, and antioxidant activity was $86.89 \%$ with IC50 was $47.45 \mathrm{mg} / \mathrm{L}$.
\end{abstract}

Keywords: antioxidant activity, maceration time, mundu leaves.

\section{PENDAHULUAN}

Tumbuhan mundu (Garcinia dulcis (Roxb.) Kurz) adalah tumbuhan asli Indonesia yang belum bisa dimanfaatkan secara maksimal oleh masyarakat Indonesia. Tumbuhan mundu mengandung senyawa bioaktif yang dapat berperan sebagai antibakteri, antikanker, antioksidan, dan antiinflamasi (Kosela et al., 2000). Senyawa bioaktif yang terdapat dalam bagian buah tumbuhan mundu mengandung karotenoid yang telah diuji secara kwalitatif (Puspita et al., 2017), bunga mengandung antioksidan sebesar 6,0 $\mu \mathrm{g} / \mathrm{mL}$ (Suwantong et al., 2013), dan kulit batang mengandung antioksidan sebesar 3,750 ppm (Ainiyah dan Ersam, 2006).

Menurut Hariana (2011) daun tumbuhan mundu memiliki banyak senyawa bioaktif seperti saponin, flavonoid, dan tanin yang berguna untuk mengobati berbagai macam penyakit seperti gondok, sariawan, dan diare. Santosa dan Heresmita (2015) melaporkan bahwa aktivitas antioksidan dari daun mundu memiliki nilai IC50 tertinggi yaitu $36,381 \mu \mathrm{g} / \mathrm{mL}$ jika dibandingkan dengan daun sembung (Blueamollis (D.don) Merr.) yang memiliki nilai IC50 sebesar 299,367 $\mu \mathrm{g} / \mathrm{mL}$, daun nampong (Siegesbeckia orientalis L.) yang memiliki nilai IC50 sebesar 108,492 $\mu \mathrm{g} / \mathrm{mL}$, dan daun 
jejenges (Salvia riparia H.B.K.) yang memiliki nilai IC50 sebesar 370,250 $\mu \mathrm{g} / \mathrm{mL}$ yang diekstraksi menggunakan metode maserasi dalam pelarut metanol.

Ekstraksi adalah cara yang digunakan untuk mendapatkan senyawa bioaktif pada daun mundu. Ekstraksi dapat dilakukan dengan berbagai metode seperti maserasi, sokletasi, perkolasi, dan ultrasonik. Maserasi dilakukan dengan memasukkan bubuk simplisia dan pelarut yang sesuai ke dalam wadah inert yang tertutup rapat pada suhu kamar. Metode maserasi mempunyai kelebihan yaitu biayanya murah, mudah dilakukan, mudah diaplikasikan, tidak memerlukan alat-alat khusus, dan tidak memerlukan pemanasan (Voight, 1995).

Pelarut yang digunakan dalam penelitian dilakukan oleh Santosa dan Heresmita pada maserasi daun mundu adalah pelarut metanol dan wazbenzen yang termasuk pelarut yang bersifat toksik, maka pada penelitian ini digunakan pelarut etanol 96\% karena pelarut ini biasa digunakan dalam ekstraksi sampel tumbuhan serta mempunyai sifat yang mampu melarutkan hampir semua zat polar, semi polar, dan non polar (Arifin et al., 2006). Etanol mempunyai konstanta dielektrik sebesar 24,3 (Sudarmadji et al., 1997) dan etanol dapat digunakan untuk menguji tanin, fenol, flavonoid, dan antioksidan (Cowan, 1999). Keuntungan penggunaan pelarut etanol adalah tidak beracun dan tidak berbahaya, digunakan etanol karena antioksidan yang hendak diekstrak diharapkan dapat diaplikasikan pada bahan makanan (Soviana, 2011).

Faktor yang mempengaruhi hasil akhir ekstraksi salah satunya adalah waktu maserasi, semakin lama waktu maserasi maka semakin lama juga bahan yang akan kontak dengan pelarut sehingga mengakibatkan pecahnya dinding sel pada bahan dan mengeluarkan zat terlarut (solute) ke dalam pelarut (solvent). Semakin lama waktu ekstraksi, kuantitas bahan yang terekstrak juga akan semakin meningkat dikarenakan kesempatan untuk bersentuhan antara bahan dengan pelarut makin besar sehingga hasilnya akan bertambah sampai titik optimum. Waktu maserasi yang melewati waktu optimum akan merusak zat terlarut yang ada di dalam bahan dan berpotensi meningkatkan proses hilangnya senyawa-senyawa pada larutan karena penguapan (Kemit et al., 2016).

Waktu maserasi yang tepat pada analisis antioksidan dari beberapa daun mempunyai perbedaan seperti daun black mullbarry yang menunjukan hasil terbaik jika dimaserasi selama 72 jam (Galih, 2018), daun belimbing wuluh selama 48 jam (Yulianingtyas dan Kusmartono, 2016), daun alpukat selama 30 jam (Kemit et al., 2016) dan daun mangrove selama 24 jam (Nurlita, 2018). Belum diketahui waktu yang tepat untuk melakukan ekstraksi daun mundu, sehingga penelitian ini bertujuan untuk mengetahui pengaruh waktu maserasi 
terhadap aktivitas antioksidan daun mundu dan mendapatkan waktu maserasi yang tepat sehingga diperoleh aktivitas antioksidan tertinggi.

\section{METODE PENELITIAN}

\section{Tempat dan Waktu Penelitian}

Penelitian

dilaksanakan

di

Laboratorium

Analisis

Pangan,

Laboratorium Rekayasa Proses dan

Pengendalian Mutu, dan Laboratorium

Pengolahan Pangan, Fakultas Teknologi

Pertanian, Universitas Udayana. Penelitian

dilaksanakan pada bulan Juni-Agustus 2019.

\section{Bahan dan Alat}

Bahan yang digunakan dalam penelitian ini adalah daun mundu yang berasal dari 2-3 tangkai pucuk daun teratas yang diperoleh dari pohon mundu yang berada di kebun belakang rumah yang berada di Dusun Larangan, Desa Tebel, Kecamatan Bareng, Kabupaten Jombang, Jawa Timur. Bahan kimia yang digunakan adalah aquades, etanol 96\% (PA), $\mathrm{NaNO}_{2}(\mathrm{PA}), \mathrm{AlCl}_{3}(\mathrm{PA}), \mathrm{NaOH}(\mathrm{PA})$, reagen folin-ciocalteu, reagen folin denis, $\mathrm{Na}_{2} \mathrm{CO}_{3}$ (PA), standar asam galat, standar quersetin, standar asam tanat, sodium karbonat, dan air es.

Alat-alat yang digunakan dalam penelitian ini adalah oven (Memmert), blender, timbangan analitik (Shimadzu), ayakan 60 mesh (Retsch), rotary vakum evaporator (Ika Labortechnik), spektrofotometer UV-Vis (Genesys 10S Uv-
Vis), kertas saring Whatman 1, shaker, mikropipet (Socorex), botol timbang (Pryrex), tabung reaksi (Pyrex), pipet ukur (Pyrex), gelas beker (Pyrex), labu ukur (Pyrex) dan alat-alat gelas lainnya.

\section{Pelaksanaan Penelitian}

Tahap pelaksanaan penelitian meliputi dua tahapan yaitu tahap pembuatan bubuk daun mundu dan proses ekstraksi daun mundu.

\section{Pembuatan Bubuk Daun Mundu}

Daun mundu dicuci bersih dan dipotong-potong dengan ukuran $0,3-0,5 \mathrm{~cm}$, kemudian dikeringkan dengan menggunakan oven pada suhu $50^{\circ} \mathrm{C}$ selama 4 jam, selanjutnya dihaluskan dengan menggunakan blender dan diayak dengan ayakan 60 mesh. Bubuk daun mundu kemudian diekstraksi.

\section{Ekstraksi Daun Mundu}

Daun mundu diekstrak menggunakan metode maserasi dengan cara bubuk daun mundu ditimbang masing masing 10 gram dan ditambahkan pelarut etanol 96\% dengan perbandingan bahan dan pelarut 1:10, selanjutnya dimaserasi seusuai perlakuan (12 jam, 24 jam, 36 jam, 48 jam, 60 jam, dan 72 jam) pada suhu kamar, setelah melakukan maserasi pada waktu yang ditentukan larutan disaring menggunakan kertas Whatman no 1, kemudian filtrat yang diperoleh diuapkan dengan rotary vakum evaporator, maka diperoleh ekstrak daun mundu. 


\section{Rancangan Percobaan}

Penelitian ini menggunakan rancangan acak lengkap (RAL) dengan perlakuan waktu maserasi. Faktor waktu ekstraksi (T) terdiri dari 3 taraf yaitu $\mathrm{T} 1=12$ jam; $\mathrm{T} 2=24$ jam; $\mathrm{T} 3=36 \mathrm{jam} ; \mathrm{T} 4=48$ jam; $\mathrm{T} 5=60 \mathrm{jam} ; \mathrm{T} 6=72 \mathrm{jam}$. Perlakuan diulang sebanyak tiga kali sehingga didapatkan 18 unit percobaan. Data yang diperoleh dianalisis menggunakan sidik ragam dan apabila terdapat pengaruh perlakuan terhadapan variabel yang diamati, maka akan dilanjutkan dengan uji Duncan (Steel and Torrie, 1993).

\section{Variabel yang Diamati}

Variabel yang diamati dalam penelitian ini yaitu Rendemen (Jayanudin $e t$ al., 2014), total tanin dengan metode Folin Denis (Rajan et al., 2012), total flavonoid
(Josipofic et al., 2016), total fenol dengan metode Folin-Ciocalteu (Garcia et al., 2007), dan aktivitas antioksidan dengan metode 1,1-diphenyl-2-picrylhydrazil (DPPH) (Mosquera et al., 2009).

\section{Analisis Data}

Data yang diperoleh dianalisis ragam menggunakan SPSS yang kemudian jika berpengaruh dilanjutkan dengan uji Duncan dengan taraf signifikansi sebesar $5 \%$.

\section{HASIL DAN PEMBAHASAN}

Nilai rata-rata dari rendemen, total tanin, total flavonoid, total fenol, dan aktivitas antioksidan ekstrak daun mundu dengan perlakuan lama waktu maserasi yang berbeda dapat dilihat pada Tabel 1 .

Tabel 1. Nilai rata-rata dari rendemen, total tanin, total flavonoid, total fenol, dan aktivitas antioksidan ekstrak daun mundu pada perlakuan waktu maserasi.

\begin{tabular}{|c|c|c|c|c|c|}
\hline $\begin{array}{c}\text { Waktu } \\
\text { Maserasi } \\
\text { (Jam) }\end{array}$ & $\begin{array}{c}\text { Rendemen } \\
(\%)\end{array}$ & $\begin{array}{l}\text { Total Tanin } \\
\text { (mg.TAE/g) }\end{array}$ & $\begin{array}{c}\text { Total } \\
\text { Flavonoid } \\
\text { (mg.QE/g) }\end{array}$ & $\begin{array}{l}\text { Total Fenol } \\
\text { (mg.GAE/g) }\end{array}$ & $\begin{array}{c}\text { Aktivitas } \\
\text { Antioksidan } \\
(\%)\end{array}$ \\
\hline $\mathrm{T} 1$ (12) & $23,10 \pm 0,14 \mathrm{ab}$ & $123,21 \pm 2,43 \mathrm{~b}$ & $348,84 \pm 7,66 b$ & $129,46 \pm 1,25 \mathrm{~b}$ & $82,93 \pm 0,81 \mathrm{~b}$ \\
\hline T2 (24) & $25,50 \pm 0,06$ a & $133,04 \pm 1,92 \mathrm{a}$ & $364,36 \pm 1,23 \mathrm{a}$ & $143,82 \pm 3,63 \mathrm{a}$ & $86,89 \pm 0,61 \mathrm{a}$ \\
\hline T3 (36) & $20,83 \pm 0,15 b c$ & $109,88 \pm 1,71 \mathrm{c}$ & $326,60 \pm 3,14 c$ & $124,32 \pm 0,65 b$ & $80,89 \pm 0,88 \mathrm{c}$ \\
\hline $\mathrm{T} 4(48)$ & $18,13 \pm 0,17 \mathrm{~cd}$ & $107,07 \pm 1,64 \mathrm{c}$ & $321,45 \pm 5,90 \mathrm{c}$ & $109,12 \pm 0,62 \mathrm{c}$ & $80,08 \pm 0,47 \mathrm{c}$ \\
\hline T5 (60) & $17,53 \pm 0,22 \mathrm{~d}$ & $98,16 \pm 3,93 \mathrm{~d}$ & $296,73 \pm 9,22 \mathrm{~d}$ & $97,77 \pm 2,11 \mathrm{~d}$ & $78,86 \pm 0,47 \mathrm{~d}$ \\
\hline T6 (72) & $16,76 \pm 0,11 \mathrm{~d}$ & $79,82 \pm 6,55 \mathrm{e}$ & $280,33 \pm 6,66 \mathrm{e}$ & $82,04 \pm 4,43 \mathrm{e}$ & $76,73 \pm 0,47 \mathrm{e}$ \\
\hline
\end{tabular}

\section{Rendemen}

Analisis ragam menunjukan bahwa perlakuan waktu maserasi berpengaruh nyata $(\mathrm{p}<0,05)$ terhadap rendemen ekstrak daun mundu. Hasil penelitian yang telah dilakukan menunjukan bahwa rendemen tertinggi diperoleh dari perlakuan dengan waktu maserasi selama 24 jam (T2) yaitu $25,50 \%$ sedangkan rendemen paling rendah diperoleh dari perlakuan dengan 
menggunakan waktu maserasi selama 72 Jam (T6) yaitu sebesar 16,76 \%. Hasil penelitian menunjukan kecenderungan waktu maserasi yang semakin lama menghasilkan rendemen yang semakin rendah, hal ini kemungkinan disebabkan karena waktu maserasi selama 72 jam (T6) sudah mengalami proses oksidasi dan proses ekstraksi sudah mengalami kejenuhan dimana waktu maserasi yang optimal terjadi padawaktu 24 jam (T2).

Menurut Asendy (2018) semakin lama waktu maserasi, maka senyawa terlarut akan terus terlarut kedalam pelarut sampai pada titik jenuh pelarut tersebut, hal ini akan menyebabkan hasil rendemen tidak lagi bertambah namun cenderung tetap atau mengalami penurunan yang tidak signifikn. Utami (2009) melaporkan bahwa waktu ekstraksi yang terlalu lama yang melewati titik optimum titik ekstraksi akan menyebabkan rusaknya senyawa kimia yang terekstrak sehingga bisa mempengaruhi hasil dari ekstraksi yang didapat dan rendemen akan menurun.

\section{Total Tanin}

Analisis ragam menunjukan bahwa perlakuan waktu maserasi berpengaruh nyata $(\mathrm{p}<0,05)$ terhadap total tanin ekstrak daun mundu. Hasil penelitian yang telah dilakukan menunjukan bahwa total tanin tertinggi diperoleh dari perlakuan dengan waktu maserasi selama 24 jam (T2) yaitu 133,04 mg.TAE/g sedangkan nilai total tanin paling rendah diperoleh dari perlakuan dengan menggunakan waktu maserasi selama 72 Jam (T6) yaitu sebesar 79,82 mg.TAE/g. Hasil penelitian menunjukan kecenderungan waktu maserasi yang semakin lama menghasilkan total tanin yang semakin rendah, hal ini diduga karena telah terjadi oksidasi antara bahan dan pelarut sehingga membuat rusaknya senyawa tanin saat terjadinya proses ekstraksi pada daun mundu.

Menurut Eriani (2017) kadar tanin akan rusak jika terjadi dalam waktu maserasi yang terlalu lama, hal ini disebabkan karena semakin lama waktu ekstraksi, kontak pelarut dan bahan akan semakin lama sedangkan setiap bahan mempunyai batas optimum waktu maserasi, jika waktu melampaui batas optimum ekstraksi akan menjadi tidak berpengaruh dikarenakan senyawa akan mengalami dekomposisi.

\section{Total Flavonoid}

Analisis ragam menunjukan bahwa perlakuan waktu maserasi berpengaruh nyata $(\mathrm{p}<0,05)$ terhadap total flavonoid ekstrak daun mundu. Hasil penelitian yang telah dilakukan menunjukan bahwa total flavonoid tertinggi diperoleh dari perlakuan dengan waktu maserasi selama 24 jam (T2) yaitu 364,36 mg.QE/g sedangkan total flavonoid paling rendah diperoleh dari perlakuan dengan menggunakan waktu maserasi selama 72 Jam (T6) yaitu sebesar 280,33 mg.QE/g. Hasil penelitian menunjukan kecenderungan waktu maserasi yang semakin lama menghasilkan total 
flavonoid yang semakin rendah, hal ini diduga karena telah terjadi oksidasi antara bahan dan pelarut sehingga membuat rusaknya senyawa kimia saat terjadinya proses ekstraksi pada daun mundu.

Menurut Asendy (2018) semakin lama waktu maserasi maka semakin lama pula kontak antara bahan dengan pelarut sehingga mengakibatkan senyawa flavonoid mengalami peningkatan, namun bila maserasi yang terlalu lama dapat mengakibatkan penurunan senyawa flavonoid ekstrak. Hal ini dikarenakan waktu maserasi yang terlalu lama mengakibatkan senyawa flavonoid yang terekstrak menjadi rusak.

Titik optimal besarnya flavonoid daun mundu berada diwaktu 24 jam yang disebabkan karena laju difusi flavonoid dari permukaan padatan ke pelarut sama besarnya dengan difusi flavonoid dari pelarut ke permukaan padatan sehingga konsentrasi flavonoid dalam pelarut sudah dalam kesetimbangan, namun setelah melewati waktu optimum tersebut maka total flavonoid akan mengalami penurunan, hal ini juga sesuai dengan pernyataan Yulianingtyas dan Kusmartono (2016) bahwa penambahan waktu maserasi diatas titik optimum tidak lagi efektif untuk meningkatkan berat flavonoid terekstrak namun yang terjadi justru berat flavonoid terekstrak cenderung menurun.

Besarnya total flavonoid daun mundu dibandingkan dengan senyawa bioaktif yang lain disebabkan karena kandungan utama dari ekstrak daun mundu ini adalah dari jenis flavonoid, hal ini sesuai dengan penelitian yang telah dilakukan oleh Santosa dan Haresmita (2015) bahwa setelah dilakukan analisis secara kualitatif menggunakan kromatografi lapis tipis (KLT) pada daun mundu didapatkan hasil yaitu ekstrak metanolik garcinia dulcis (Roxb.) mengandung senyawa golongan fenol dan flavonoid.

Hutagalung (2019) melaporkan bahwa hasil analisis senyawa flavonoid daun tumbuhan mundu (garcinia dulcis (Roxb.)) dengan menggunakan Spektrofotometer UV-Vesible, Spektrofotometer FT-IR, Spektrofotometer H-NMR menunjukan bahwa senyawa utama hasil isolasi diduga adalah senyawa flavonoid dengan jenis bilavonoid. Tamhid (2019) juga melaporkan bahwa senyawa flavonoid yang sudah diisolasi dari daun mundu (garcinia dulcis (Roxb.)) adalah flavon, flavan, isovlavon, dan bivlavonoid dengan kandungan utama yaitu bivlavonoid yang jumlahnya kurang lebih setengahnya. Senyawa bivlavonoid banyak ditemukan dalam tanaman dengan keluarga Guttiferae (Cluseaceae) terutama genus garcinia yang didalamnya termasuk tumbuhan mundu (garcinia dulcis (Roxb.))

\section{Total Fenol}

Analisis ragam menunjukan bahwa perlakuan waktu maserasi berpengaruh nyata $(p<0,05)$ terhadap total fenol ekstrak daun mundu, data total fenol dapat dilihat 
pada Tabel 1. Hasil penelitian yang telah dilakukan menunjukan bahwa total fenol tertinggi diperoleh dari perlakuan dengan waktu maserasi selama 24 jam (T2) yaitu 143,82 mg.GAE/g sedangkan total fenol paling rendah diperoleh dari perlakuan dengan menggunakan waktu maserasi selama 72 Jam (T6) yaitu sebesar 82,04 mg.GAE/g, waktu maserasi maserasi berpengaruh nyata terhadap total fenol dari ekstrak daun mundu.

Hasil penelitian menunjukan kecenderungan waktu maserasi yang semakin lama menghasilkan total fenol yang semakin rendah, hal ini diduga karena telah terjadi oksidasi antara bahan dan pelarut sehingga membuat rusaknya senyawa fenol saat terjadinya proses ekstraksi pada daun mundu. Hal ini sesuai dengan pernyataan Cikita et al. (2016) bahwa Waktu maserasi yang melewati waktu optimum akan merusak zat terlarut yang ada didalam bahan dan berpotensi meningkatkan proses hilangnya senyawa-senyawa pada larutan karena oksidasi.

\section{Aktivitas Antioksidan}

Analisis ragam menunjukan bahwa waktu maserasi berpengaruh nyata $(\mathrm{p}<0,05)$ terhadap aktivitas antioksidan ekstrak daun mundu, data aktivitas antioksidan dapat dilihat pada Tabel 1. Hasil penelitian yang telah dilakukan menunjukan bahwa aktivitas antioksidan tertinggi diperoleh dari perlakuan dengan waktu maserasi selama 24 jam (T2) yaitu $86,89 \%$ sedangkan aktivitas antioksidan paling rendah diperoleh dari perlakuan dengan menggunakan waktu maserasi selama 72 Jam (T6) yaitu sebesar $76,73 \%$.

Hasil penelitian menunjukan kecenderungan waktu maserasi yang semakin lama menghasilkan aktivitas antioksidan yang semakin rendah, hal ini diduga karena telah terjadi oksidasi antara bahan dan pelarut sehingga membuat rusaknya senyawa kimia saat terjadinya proses ekstraksi pada daun mundu yang mengakibatkan terjadinya penurunan aktivitas antioksidan ekstrak daun mundu. Hal ini didukung dengan semakin lama waktu maserasi maka rendemen, total tanin, total flavonoid, dan total fenol akan semakin menurun.

Berdasarkan hasil analisis aktivitas antioksidan, diperoleh bahwa perlakuan maserasi dengan perlakuan waktu maserasi selama 24 jam memiliki persentase aktivitas antioksidan tertinggi sehingga perlakuan ini dipilih untuk diuji penentuan IC50.Grafik hubungan antara konsentrasi ekstrak dengan aktivitas antioksidan ekstrak daun mundu dalam berbagai konsentrasi dapat dilihat pada Gambar 3. 


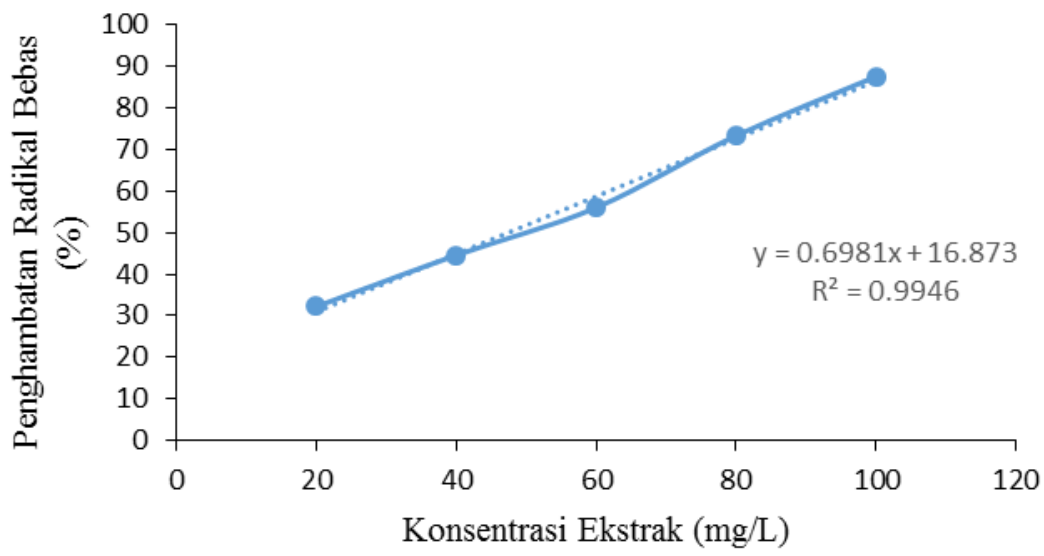

Gambar 3. Grafik hubungan antara konsentrasi ekstrak dengan aktivitas antioksidan (\%)

Gambar 3 menunjukkan bahwa semakin tinggi konsentrasi ekstrak maka semakin tinggi persentase aktivitas antioksidan. Berdasarkan analisis regresi linier diperoleh persamaan $\mathrm{y}=0.6981 \mathrm{x}+$ 16.873 dengan nilai IC50 sebesar 47,45 $\mathrm{mg} / \mathrm{L}$. Semakin rendah nilai IC50 maka semakin besar juga kemampuan antioksidannya. Menurut Blois (1958) suatu senyawa memiliki aktivitas antioksidan yang sangat kuat apabila memiliki nilai IC50 $<50 \mathrm{mg} / \mathrm{L}$, sehingga dalam penelitian ini ekstrak daun mundu dapat dikategorikan dalam antioksidan yang sangat kuat.

$$
\text { Santosa dan Haresmita }
$$
mengatakan bahwa daun mundu mempunyai aktivitas antioksidan yang sangat kuat karena mempunyai nilai IC50 yang kecil. Daun mundu (Garcinia dulcis (Roxb.)) mempunyai senyawa fenol termasuk flavonoid yang berperan sebagai antioksidan potensial. Aktivitas antioksidan senyawa bioaktif bertumpu pada kemampuan reduksi-oksidasi yang telah dimilikainya sehingga mampu menyerap radikal bebas, mengikat oksigen singlet dan triplet, maupun mendengkomposisi peroksida.

\section{KESIMPULAN DAN SARAN}

\section{Kesimpulan}

Perlakuan waktu maserasi ekstrak daun mundu berpengaruh nyata terhadap rendemen, total tanin, total flavonoid, total fenol, dan aktivitas antioksidan. Perlakuan terbaik adalah perlakuan waktu maserasi selama 24 jam dengan hasil rendemen sebesar $24,67 \%$, total tanin 133,04 mg.TAE/g, total flavonoid 364,36 mg.QE/g, total fenol 143,82 mg.GAE/g, dan aktivitas antioksidan sebesar 86,89\% dengan IC50 sebesar $47,45 \mathrm{mg} / \mathrm{L}$

\section{Saran}

Berdasarkan hasil penelitian ini dapat disarankan untuk menggunakan waktu maserasi selama 24 jam jika melakukan ekstraksi pada daun mundu (Garcinia dulcis (Roxb.)) menggunakan pelarut etanol 96\% dan perlu dilakukan penelitian lanjutan 
tentang pengaplikasian daun mundu menjadi produk makanan seperti teh, loloh, serta produk bahan pangan yang lain.

\section{DAFTAR PUSTAKA}

Ainiyah, N. dan T. Ersam. 2006. Tiga turunan santon dari kulit batang mundu Garcinia dulcis (Roxb.) Kurz. Sebagai antioksidan. Tesis. Tidak dipublikasikan. Fakultas Mipa ITS, Surabaya.

Arifin, H., N. Anggraini, D. Handayani, dan R. Rasyid. 2006. Standarisasi ekstrak etanol daun Eugenia cumini Merr. Jurnal Sains Teknologi Farmasi. 11(2): 88-93.

Asendy, D. A., Pengaruh waktu maserasi terhadap aktivitas antioksidan ekstrak kulit buah jeruk lemon (Citrus limon Linn). Skripsi. Tidak dipublikasikan. Universitas Udayana. Bali.

Blois, M.S. 1959. Antioksidant determinations by the use of a stable free radical. J. Nature. $181: 1199-1200$.

Cikita, I., I. H. Hasibuan dan R. Hasibuan. 2016. Pemanfaatan flavonoid ekstrak daun katuk Sauropus androgynous Merr) sebagai antioksidan pada minyak kelapa. Jurnal Teknik Kimia USU. Jurnal Teknik Kimia USU: 1-7.

Cowan, M.M. 1999. Plant products as antimicrobial agents. Clinical Microbiology Reviews 12(4) : 564-82.

Eriani, W. 2017. Pengaruh waktu maserasi, perlakuan bahan dan zat fiksasi pada pembuatan warna alami daun ketapang (Termanilia cattapa Linn). Skripsi S1. Tidak dipublikasikan. Progam Studi Teknik Kima, Universitas Muhamadiyah Surakarta.

Galih, P. M. 2018. Pengaruh konsentrasi pelarut dan waktu maserasi terhadap sifat fitiokimia daun black mulberry (Morus nigra L.). Skripsi S1. Tidak dipublikasikan, Jurusan Teknologi Pangan Universitas Pasundan, Bandung.

Garcia, C.A., G. Gavino, M. B. Mosqueda, P. Hevia, dan V. C. Gavino. 2007. Correlation of tocopherol, tokotrienol, yoryzanol and total polyphenol content in rice bran with different antioxidant capacity assays. Journal Food Chemistery 102(1): 1228-1232.
Hariana, A. 2011. Tumbuhan obat dan khasiatnya. Penebar Swadaya, Jakarta.

Hutagalung, N. 2019. Isolasi dan identifikasi golongan senyawa flavonoid dari daun tumbuhan mundu (Garcinia dulcis (Roxb) Kurz.). Skripsi. Tidak dipublikasikan. USU. Medan.

Jayanudin, A. Z., Lestari dan F. Nurbayanti. 2014. Pengaruh suhu dan rasio pelarut ekstraksi terhadap rendemen dan viskositas natrium alginate dari rumput laut coklat (Sargassum limon). Jurnal Integritas Proses. 5(1): 51-56.

Josipovic, A., R. Sudar, A. Sudaric, V. Jurkovic, M.M. Kocar dan A.M. Kulundzic. 2016. Total phenolic and total flavonoid content variability of soybean genotypes in eastern croatia. Croatia Journal Food Science Technology. 8(2): 60-65.

Kemit, N., I W. R. Widarta, dan K. A. Nocianitri. 2016. Pengaruh jenis pelarut dan waktu maserasi terhadap kandungan senyawa flavonoid dan aktivitas antioksidan ekstrak daun alpukat (Persea americana Mill). Jurnal Ilmu dan Teknologi Pangan. 5(2):130-141.

Kosela, S., L. H. Hu, T. Rachmatiah, M. Hanafi dan K. Y. Sim. 2000. Dulxhanthones F-H, three new pyranoxhanthones from Garcinia dulcis. Journal of Natural Product. 63 : 406-407.

Mosquera, O.M., Y.M. Correa dan J. Nino. 2009. Antioxidant activity of plants extract from Colombian flora Braz. J. Pharm. 19(2): 382-387.

Mustabsyiroh, Z. dan T. Ersam. 2014. Isolasi senyawa santon dari kulit akar Garcinia dulcis. Jurnal Sains dan Seni POMITS. 1(1): 1-3.

Nurlita, R. 2018. Pengaruh lama waktu maserasi terhadap aktivitas antioksidan ekstrak daun dan kulit batang mangrove sonneratia caseolaris di pesisir pantai Serang, kabupaten Blitar Jawa Timur. Skripasi S1. Tidak dipublikasikan. Fakultas Perikanan dan Kelautan Universitas Brawijaya, Malang.

Puspita, D., Y. D. Tjahyono, Y. Samalukang, dan M. Rahardjo. 2017. Potensi buah mundu (Garcinia xanthochynus (Hook.) F.) sebagai penghasil pigmen alami. Jurnal LPMM Unsoed. 1(1): 680-687.

Rajan, S., S. Mahalakshmi, V. M. Deepa, K. Sathya, S. Shajitha, dan T. 
Thirunalasundari. 2012. Antioxidant potentials of Punica granatum fruit rind extracts. International Journal of Pharmacy and Pharmaceutical Sciences. 3(3):82-88.

Santosa, D., dan P. P. Haresmita. 2015. Penentuan aktivitas antioksidan Garcinia dulcis (roxb.) kurz, Blumeamollis (don) Merr., Siegesbeckia orientalis L., dan Salvia riparia H.B.K. yang dikoleksi dari taman nasional gunung merapi dengan metode DPPH (2,2-difenil-1-pikrilhidrazil) serta profil kromatografi lapis tipisnya. Traditional Medical Journal, 20(1):28-36.

Soviana, E. 2011. Kadar fenolik dan aktivitas antiradikal dpph ekstrak gambir pada berbagai suhu ekstraksi menggunakan pelarut etanol $70 \%$. Skripsi S1. Tidak dibuplikasikan. Program Studi Gizi, Fakultas Ilmu Kesehatan, Universitas Muhammadiyah Surakarta.

Steel, R.G.D dan J.H. Torrie. 1993. Prinsip dan prosedur statistika suatu pendekatan biometrik. Penerjemah B. Sumantri. PT. Gramedia Pustaka, Jakarta.

Sudarmadji, S., B. Haryono dan Suharji. 1997. Prosedur analisis untuk bahan makanan dan pertanian. Penerbit Liberti. Yogyakarta
Suwantong, O., P. Pankongadisak., S. Deachathai, dan P. Supaphol. 2013.The potential of electrospun poly (1-lactic acid) fiber mats containing a crude Garcinia dulcis extract for use as wound dressings. Ciang Mai Journal Science. 40(3): 517-533.

Tamhid, H. A. 2019. Chemical compounds and antibacterial activity of Garcinia dulcis (Roxb.) Kurz. Jurnal Kedokteran dan Kesehatan Indonesia. 10(1): 71-85.

Utami. 2009. Potensi daun alpukat (Persea americana Mill) sebagai sumber antioksidan alami. Jurnal Teknik Kimia UPN. Jawa Timur. Vol 2 (1) : 58-64.

Voight, R. 1995. Buku pelajaran teknologi farmasi, Penerjemah Soendari Noerono. Gajah Mada University Press, Yogyakarta, 566- 567.

Widarta, I.W.R dan I.W. Arnata. 2017. Ekstraksi komponen bioaktif daun alpukat dengan bantuan ultrasonik pada berbagai jenis dan konsentrasi pelarut. Jurnal AGRITECH, 37(2):148-157.

Yulianingtyas, A., dan B. Kusmartono. 2016. Optimasi volume pelarut dan waktu maserasi pengambilan flavonoid daun belimbing wuluh (Averrhoa bilimbi L.). Jurnal Teknik Kimia 10(2):58-64. 